\title{
Styrylpyrone-class compounds from medicinal fungi Phellinus and Inonotus spp., and their medicinal importance
}

\author{
In-Kyoung Lee and Bong-Sik Yun
}

\begin{abstract}
Members of the genera Phellinus and Inonotus, including P. linteus, P. igniarius, P. ribis, I. obliquus and I. xeranticus are well-known medicinal fungi (mushrooms) and have been used in treatment of cancer, diabetes, bacterial and viral infections and ulcer. Adverse effects of these medicinal mushrooms have not yet been reported, indicating the safe nature of these mushrooms. Polysaccharides, particularly $\beta$-glucan, are considered the compounds responsible for the biological activity of medicinal mushrooms. However, there is only a limited amount of evidence to indicate that polysaccharides are in fact responsible for the biological effects of these medicinal mushrooms. Recently, many research groups have begun identification of active low-MW compounds in medicinal mushrooms, with a focus on the yellow polyphenol pigments, which are composed of a styrylpyrone class of compounds. Interestingly, a representative group of medicinal fungi, including $P$. linteus, P. igniarius, P. ribis, $I$. obliquus and $I$. xeranticus were shown to produce a large and diverse range of styrylpyrone-type polyphenol pigments that exhibited various biological activities, including anti-oxidative, anti-inflammatory, cytotoxic, anti-platelet aggregation, anti-diabetic, anti-dementia and anti-viral effects. Styrylpyrone pigments in mushrooms are thought to have a role similar to that of flavonoids in plants. The unique and unprecedented carbon skeleton of fused styrylpyrone might be an attractive molecular scaffold for pharmacological applications. In this review, the structural diversity, biological effects and biogenesis of styrylpyrone-class polyphenols from medicinal fungi are described.
\end{abstract}

The Journal of Antibiotics (2011) 64, 349-359; doi:10.1038/ja.2011.2; published online 9 February 2011

Keywords: biological activity; Inonotus; medicinal mushrooms; Phellinus; styrylpyrone

\section{INTRODUCTION}

Mushrooms are ubiquitous in nature and are a good source of food with high nutritional attributes. Some mushrooms have been shown to be physiologically beneficial to humans and to produce various classes of structurally unique and biologically active metabolites that exhibit significant anti-microbial, anti-tumor and anti-viral activities. ${ }^{1-5}$ Members of the genera Phellinus and Inonotus, including P. linteus, P. ribis, P. igniarius, I. obliquus, and I. xeranticus, have been used as traditional medicines for treatment of gastrointestinal cancer, cardiovascular disease, tuberculosis, liver or heart disease, fester, bellyache, blood gonorrhea, stomach ailment and diabetes. ${ }^{6}$ However, despite increased usage, their pharmacological actions have not been well established. Polysaccharides, particularly $\beta$-glucan, are believed to be responsible for the biological activity of medicinal mushrooms, and a number of polysaccharides and protein-bound polysaccharides have been used clinically for treatment of cancer. Examples include the polysaccharopeptide Krestin from Coriolus versicolor, ${ }^{7}$ Mesima from P. linteus, ${ }^{8}$ Lentinan from Lentinus edodes, ${ }^{9}$ and Schizophylan from Schizophyllum commune..$^{10}$ These polysaccharides have been developed and used extensively as anti-cancer drugs in Asia. Although an overwhelming number of reports have been published on the importance of polysaccharides as immunomodulating agents, not all of the curative properties found in these medicinal fungi could be fully accounted for. ${ }^{11-15}$

Recently, these medicinal fungi have been reported to produce a variety of yellow polyphenol pigments, known as styrylpyrones, which have shown significant biological effects, such as anti-oxidative, anti-cancer, anti-platelet, anti-diabetic, anti-inflammatory and antiviral activities. Since the first isolation of hispidin (1) as a naturally occurring styrylpyrone from Inonotus hispidus (formerly Polyporus hispidus) in 1889, a number of other styrylpyrone metabolites from Phellinus and Inonotus have been discovered. Styrylpyrone pigments are common constituents of fungi, mainly those belonging to the Hymenochaetaceae family, including Phellinus and Inonotus. ${ }^{16}$ They also exist in primitive angiosperm families, including Piperaceae, Lauraceae, Annonaceae, Ranuculaceae and Zingiberaceae, where they have an important role in defense against mechanical wounding or microbial attack, and show potent biological activities, including 
anti-cancer and sedative effects. ${ }^{17,18}$ Biogenesis of fungal styrylpyrones and their intrinsic role in fungi, like the phenylpropanoid derivatives of plants, which have important ecological and physiological roles, have attracted much attention. Styrylpyrones are regarded as phenylalanine (Phe)-derived fungal metabolites with a variety of functions, including defense, pigmentation and signaling molecules.

Classification of fungal metabolites based on their putative biosynthesis was first reported by Turner and Aldridge. ${ }^{19}$ Subsequently, in 1987, Gill and Steglich ${ }^{20}$ conducted a comprehensive study of styrylpyrones isolated from fungi belonging to the macromycetes. Gill continued this work, and reported on a variety of fungal pigments from 1986 to $2001 .^{21-23}$ They were classified as styrylpyrones according to their biogenesis by Dewick, who introduced styrylpyrone and kavapyrone derived from the plant Piper methysticum. ${ }^{18}$ Styrylpyrones were not discovered until 30 years after hispidin (1) and several of its dimers were isolated in the mid $1970 \mathrm{~s}$.

This review includes a discussion of styrylpyrone metabolites isolated from Phellinus and Inonotus during the past 10 years, and a presentation on recent progress in isolation, structural diversity, biological activities and biosynthesis of styrylpyrones from these medicinal fungi.

\section{STRUCTURAL DIVERSITY OF STYRYLPYRONES}

Hispidin (1) and bisnoryangonin (2) may be the best-known examples of styrylpyrones. Compound $\mathbf{1}$ was first isolated from I. hispidus by Zopf in 1889, but was first identified as 6-(3',4'-dihydroxystyryl)-4hydroxy-2-pyrone by Edwards in 1961 and by Bu'Lock in 1962. ${ }^{20}$ Labeling experiments in cultures of I. hispidus and Phaeolus schweinitzii have demonstrated that the styryl group is derived from Phe via cinnamic acid, $p$-coumaric acid and caffeoyl-CoA pathways, whereas the pyrone ring is derived from acetate. ${ }^{24-26}$ In addition, compound 1 was shown to be biosynthesized by hydroxylase, which catalyzes hydroxylation of compound $\mathbf{2}$. Compounds $\mathbf{1}$ and $\mathbf{2}$ were isolated from fungi belonging to the genera Gymnopilus, Hypholoma and Pholiota in the Agaricales, and genera belonging to the family Hymenochaetaceae in the Aphyllophorales (Table 1). However, bisnoryangonin has been found mainly in the Agaricales, and trace amounts have been identified in Phellinus and Inonotus. Since hispidin (1) was first reported as a PKC (protein kinase C) inhibitor in 1977, it has been commercially available for use in standard experiments associated with PKC. $^{27}$ Compound 1 from mycelial cultures of $P$. linteus exhibited anti-oxidative and $\beta$-secretase inhibitory activities. ${ }^{28,29}$

Remarkably, various hispidin-classes of metabolites have been biogenerated by dimerization or oligomerization of styrylpyrone building blocks (Figure 1). Hispidin (1) and bisnoryangonin (2) may polymerize during maturation of fungi and production of fungal lignin. Steglich and coworkers characterized 3,14'-bihispidinyl (3) from $P$. pomaceus ${ }^{30}$ and hypholomines A (4) and B (5) and fasciculines A (6) and B (7) from Hypholoma fasciculare. ${ }^{31}$ Fiasson reported on the presence of hispidin (1) and its two dimers, hypholomine B and 3,14'bihispidinyl, in Phellinus and Inonotus. ${ }^{16}$ Recently, the structurally intriguing phelligridimer A (8) was isolated from P. igniarius, ${ }^{32}$ and two unprecedented 3,3'-fused bis-styrylpyrones, named squarrosidine (9) and pinillidine (10), were isolated from Pholiota squarrosa and P. pini, respectively. ${ }^{33}$ Compound $\mathbf{1 0}$ has the same structure as 1,1distyrylpyrylethan, which was previously isolated from the fruiting body of Phaeolus schweinitzii. ${ }^{20}$ Occurrence of styrylpyrones in different families implies that they may have similar ecological roles, such as scavenging for reactive oxygen species in oxidative stress. Recently, we found that hispidin (1) and its dimeric compounds, 3,14'-bihispidinyl
(3), hypholomine B (5) and 1,1-distyrylpyrylethan (10), existed in cultured broths of $I$. xeranticus and P. linteus. ${ }^{34}$ These compounds exhibited significant free radical scavenging activity. Hispidin (1) and hypholomine B (5) were the most abundant metabolites and were found to be responsible for the anti-oxidative activity of the crude extract. Caffeic acid (11), a precursor of hispidin biosynthesis, was found to be highly accumulated in culture broths containing small amounts of hispidin (1) and hypholomine B (5). The reason for this is still not clear, but may be due to weak activity of the enzymes associated with hispidin biosynthesis. Although biosynthesis of dimeric hispidins from two monomers via oxidative coupling by lignolytic enzymes, laccase and peroxidase, has been proposed, the details of this process remain unknown. In preliminary experiments, we attempted enzymatic synthesis of the hispidin dimer from hispidin (1) using commercially available horseradish peroxidase, resulting in production of a hispidin dimer, $3,14^{\prime}$-bihispidinyl (3). ${ }^{35}$ whereas the other dimers including hypholomine B (5) and 1,1-distyrylpyrylethan (10) were not detected. This result revealed the dominance of the coupling modes forming the covalent bond at C-3 and C-14' of two units of hispidin (1), and indicated that additional catalysts or substrates are needed for synthesis of other hispidin dimers. This result also suggests that hispidin redox potentials and different types of peroxidase are sufficient for generation of the biosynthetic diversity of styrylpyrones and production of many of its derivatives that have not yet been identified.

Natural anti-inflammatory and anti-arthritic agents against $3 \alpha$ hydroxysteroid dehydrogenase, cyclooxygenase and xanthine oxidase were isolated from the ethanolic extract of the fruiting body of Inonotus sp. and identified as hispidin (1), isohispidin (tautomeric $\gamma$-pyrone, 12), 4-(3,4-dihydroxyphenyl)-but-3-en-2-one (13), inonotic acid methylester (14) and inotilone (15). ${ }^{36}$ Isohispidin (12) co-occurs as a minor compound, together with hispidin (1), suggesting that hispidin is a more stable structure than isohispidin (12). These metabolites $(\mathbf{1}, \mathbf{1 2 - 1 5})$ share the same biosynthetic origin as polyketides derived from caffeoyl-CoA. The structurally unusual inotilone (15) could be the product of decarboxylation-radical ring closure from hispolon (16), which was not isolated from this fungus, but is present in I. hispidus. Inotilone (15) showed immunomodulatory, anti-cancer and anti-viral activity (Figure 2). ${ }^{37}$

A recent study of the chemical constituents of the yellow pigments in the fruiting bodies of $P$. igniarius, $P$. linteus, $I$. xeranticus and I. obliqqus afforded unique styrylpyrone derivatives with an unprecedented carbon skeleton. Phelligridins A-J (17-26; Figure 2) were isolated from the ethanolic extract of $P$. igniarius together with inoscavin A (30), hispolon (16), and 4-(3,4-dihydroxyphenyl)-but-3en-2-one (13), and showed anti-oxidative and cytotoxic effects. ${ }^{38-40}$ Phelligridins C (19) and D (20) were then isolated from P. linteus and reported as meshimakobnols $\mathrm{A}$ and $\mathrm{B}$, respectively. ${ }^{41}$ In addition, the fruiting body of $P$. linteus was also reported to produce phellifuropyranone A (27) with anti-proliferative activity against mouse melanoma and human lung cancer cells in vitro, ${ }^{42}$ and two novel furan derivatives, phellinusfurans A (28) and B (29), which displayed anticomplement activity (Figure 3). ${ }^{43}$ Phellifuropyranone A (27) was concurrently reported as inoscavin E (32), which was isolated from the fruiting bodies of I. xeranticus. ${ }^{44}$ The novel free radical scavengers, inoscavins A-E (30-33, 27), methylinoscavins A-D (34-37) and interfungin A-C (38-40) were isolated from the fruiting bodies of I. xeranticus, together with phelligridin D (20), phelligridin F (22), davallialactone (41) and methyldavallialactone (42) (Figures 3 and 4). ${ }^{45-49}$ Compound 41 was first isolated from the rhizome of a fern Davallia mariesii and shown to be cytotoxic against BALB/3T3 cells 
Table 1 Occurrence of styrylpyrone compounds from medicinal fungi

\begin{tabular}{|c|c|c|c|}
\hline Compounds & Producing fungi & Biological activity & References \\
\hline Hispidin (1) & $\begin{array}{l}\text { Inonotus hispidus, I. xeranticus, Phellinus igniarius, } \\
\text { P. pini, P. ribis, P. linteus, P. baumii. For details, } \\
\text { see ref. } 10\end{array}$ & $\begin{array}{l}\text { Anti-oxidant, cytotoxic, anti-inflammatory, } \\
\text { anti-viral, anti-dementia }\end{array}$ & $15,20,27-29,34,36,60$ \\
\hline Bisnoryangonin (2) & $\begin{array}{l}\text { Gymnopilus aeruginosa } \\
\text { For details, see ref.10 }\end{array}$ & Anti-oxidant & 20 \\
\hline 3,14'-Bihispidinyl (3) & $\begin{array}{l}\text { I. hispidus, I. xeranticus, P. linteus, P. ignarius } \\
\text { For details, see ref.10 }\end{array}$ & Anti-oxidant & $16,20,30,34,35$ \\
\hline Hypholomine A (4) & $\begin{array}{l}\text { Hypholoma elongatipes, Pholiota alnicola } \\
\text { For details, see ref.10 }\end{array}$ & & 20,31 \\
\hline Hypholomine B (5) & $\begin{array}{l}\text { Hypholoma elongatipes, Pholiota alnicola, } \\
\text { I. hispidus, I. xeranticus, P. linteus, P. ribis } \\
\text { For details, see ref.10 }\end{array}$ & Anti-oxidant, anti-diabetes, anti-inflammatory & $16,20,31,34,36,56$ \\
\hline Fasciculin A (6) & For details, see ref.10 & & 20,31 \\
\hline Fasciculin B (7) & For details, see ref.10 & & 20,31 \\
\hline Phelligridimer A (8) & P. igniarius & Anti-oxidant & 32 \\
\hline Squarrosidine (9) & Pholiota squarrosa & Anti-inflammatory & 33,36 \\
\hline $\begin{array}{l}\text { 1,1-distyrylpyry- } \\
\text { lethan=Pinillidin (10) }\end{array}$ & P. linteus, P. pini, I. xeranticus & Anti-oxidant, anti-inflammatory & $33,34,36$ \\
\hline Isohispidin (12) & Inonotus sp. & Anti-inflammatory & 36 \\
\hline Phelligridin A (17) & P. igniarius & Cytotoxic & 38 \\
\hline Phelligridin B (18) & P. igniarius & Cytotoxic & 38 \\
\hline $\begin{array}{l}\text { Phelligridin C } \\
\text { (19)=Meshinokobnol A }\end{array}$ & P. igniarius, P. linteus & Cytotoxic & 38,41 \\
\hline $\begin{array}{l}\text { Phelligridin D } \\
(\mathbf{2 0})=\text { Meshinokobnol B }\end{array}$ & $\begin{array}{l}\text { P. igniarius, P. linteus, P. baumii, I. xeranticus, } \\
\text { I. obliquus }\end{array}$ & Cytotoxic & $38,41,48,51$ \\
\hline Phelligridin E (21) & P. igniarius, I. obliquus & Cytotoxic & 38,51 \\
\hline Phelligridin F (22) & P. igniarius, I. xeranticus & Cytotoxic & 38,45 \\
\hline Phelligridin G (23) & P. igniarius, I. obliquus & Anti-oxidant, cytotoxic & 39,51 \\
\hline Phelligridin H (24) & P. igniarius & Anti-oxidant, cytotoxic & 40 \\
\hline $\begin{array}{l}\text { Phelligridin I } \\
\text { (25)=Inonoblin A }\end{array}$ & P. igniarius, I. obliquus & Anti-oxidant, cytotoxic & 40,51 \\
\hline Phelligridin J (26) & P. igniarius & Anti-oxidant, cytotoxic & 40 \\
\hline $\begin{array}{l}\text { Inoscavin E } \\
(\mathbf{2 7})=\text { Phellifuropyranone A }\end{array}$ & I. xeranticus, P. linteus & Anti-oxidant, cytotoxic & 42,44 \\
\hline Phellinusfuran A (28) & P. linteus & Anti-inflammatory & 43 \\
\hline Phellinusfuran B (29) & P. linteus & Anti-inflammatory & 43 \\
\hline Inoscavin A (30) & I. xeranticus, P. igniarius, $P$. linteus & Anti-oxidant, antidiabetes & $45,46,56$ \\
\hline Inoscavin B (31) & I. xeranticus & Anti-oxidant & 46 \\
\hline Inoscavin C (32) & I. xeranticus & Anti-oxidant & 47 \\
\hline Inoscavin D (33) & I. xeranticus & Anti-oxidant & 48 \\
\hline Methylinoscavin A (34) & I. xeranticus & Anti-oxidant & 46 \\
\hline Methylinoscavin B (35) & I. xeranticus & Anti-oxidant & 46 \\
\hline Methylinoscavin C (36) & I. xeranticus & Anti-oxidant & 47 \\
\hline Methylinoscavin D (37) & I. xeranticus & Anti-oxidant & 48 \\
\hline Interfungin A (38) & I. xeranticus, P. linteus, P. baumii & Anti-oxidant, anti-diabetes & $49,56,57$ \\
\hline Interfungin B (39) & I. xeranticus & Anti-oxidant & 49 \\
\hline Interfungin C (40) & I. xeranticus & Anti-oxidant & 49 \\
\hline Davallialactone (41) & I. xeranticus, P. igniarius, P. baumi & $\begin{array}{l}\text { Anti-oxidant, antidiabetes, anti-inflammatory, } \\
\text { anti-platelet aggregation }\end{array}$ & $47,50,56,58,59$ \\
\hline Methyldavallialactone (42) & I. xeranticus & Anti-oxidant, antidiabetes & 47,56 \\
\hline Inonoblin B (43) & I. obliquus & Anti-oxidant & 51 \\
\hline Inonoblin C (44) & 1. obliquus & Anti-oxidant & 51 \\
\hline Phellinin A1 (45) & Phellinus sp. & Anti-oxidant & 52,53 \\
\hline Phellinin A2 (46) & Phellinus sp. & Anti-oxidant & 52,53 \\
\hline
\end{tabular}

transformed with the H-ras oncogene. ${ }^{50}$ Interestingly, compound 41 was a major constituent of the medicinal fungi I. xeranticus and Phellinus spp., and showed potent and diverse biological activities, which will be discussed in the biological section. New free radical scavengers, inonoblins A-C $(25,43,44)$, were isolated from the methanolic extract of I. obliquus, along with phelligridins D (20), E (21) and G (23) (Figure 4). ${ }^{51}$ Inonoblin A (25) was re-isolated from P. igniarius and named phelligridin I. Phellinins A1 (45) and A2 (46), 
unique styrylpyrones, were isolated from the culture broth of Phellinus sp. KACC903057P, along with hispidin (1) and 1,1-distyrylpyrylethan (10).$^{52,53}$ Phellinin A was isolated as a mixture of two isomers, A1 (45) and A2 (46), which could not be separated using a general purification<smiles>[R]c1cc(/C=C/c2ccc(O)c([R])c2)oc(=O)c1</smiles>
Hispidin (1): $\mathrm{R}_{1}=\mathrm{R}_{2}=\mathrm{OH}$ Bisnoryangonin (2): $\mathrm{R}_{1}=\mathrm{OH}, \mathrm{R}_{2}=\mathrm{H}$<smiles></smiles>

Hypholomine A (4): R=H Hypholomine B (5): $\mathrm{R}=\mathrm{OH}$

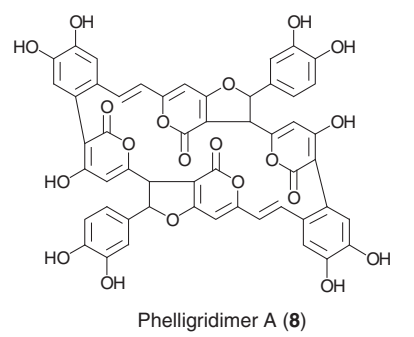

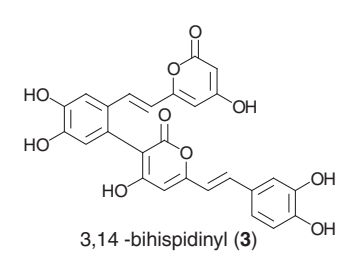

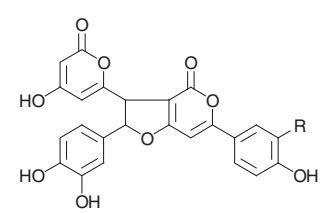

Fasciculine A (6): $\mathrm{R}=\mathrm{H}$ Fasciculine $B(7): \mathrm{R}=\mathrm{OH}$

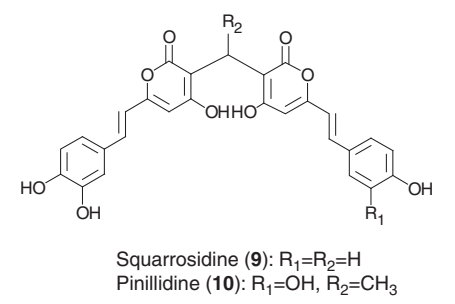

Figure 1 Structures of hispidin (1), bisnoryangonin (2) and their dimeric and tetrameric compounds. process (Figure 4). Compounds $\mathbf{4 5}$ and $\mathbf{4 6}$ could be biosynthesized by condensation of trans- $\gamma$-monocyclofarnesyl pyrophosphate and hispidin (1), followed by oxidative and non-stereoselective cyclization. Phellinin A $(45,46)$ is the first example of condensation of hispidin (1) and an isoprene unit, representing a new group of a natural polyketide-isoprenoid hybrid compounds.

\section{BIOLOGICAL ACTIVITIES OF STYRYLPYRONES}

Anti-oxidant activity

Free radicals have been implicated in pathogenesis of various human diseases, such as myocardial and cerebral ischemia, arteriosclerosis, diabetes, rheumatoid arthritis, inflammation, cancer-initiation and aging processes. Therefore, there is a growing need for free radical scavengers that can be used as protective agents against these diseases.

Styrylpyrones have been reported to have potent anti-oxidant activity. Hispidin (1) and its dimers, 3,14'-bihispidinyl (3), hypholomine B (5) and 1,1-distyrylpyrylethan (10), showed significant radical scavenging activity in a concentration-dependent manner, ${ }^{34}$ whereas dimeric hispidins possessing two catechol moieties, 3,14'-bihispidinyl (3), hypholomine B (5) and 1,1-distyrylpyrylethan (10), exhibited more potent activity than hispidin (1) for DPPH and ABTS radical scavenging activity. Therefore, the anti-oxidative effects of hispidin (1), 3,14'-bihispidinyl (3), hypholomine B (5) and 1,1-distyrylpyrylethan (10) against DPPH and ABTS radicals may have originated from the catechol moiety. Their activities are about 2-3 times more potent than those of Trolox, a well-known commercial anti-oxidant.

Inoscavins A-E (30-33, 27), methylinoscavins A-D (34-37) and interfungins A-C (38-40) from the fruiting body of I. xeranticus, and inonoblins A-C $(25,44,45)$ from the fruiting body of $I$. obliquus showed potent free radical scavenging activity (Table 1). ${ }^{4-49}$ Among the compounds tested, davallialactone (41), which was isolated by our<smiles></smiles><smiles>COC(=O)CC(=O)/C=C(O)/C=C/c1ccc(O)c(O)c1</smiles>

Caffeic acid (11) Hispidin (1) Isohispidin (12) 4-(3,4-Dihydroxyphenyl)but3-en-2-one (13)<smiles>CC(=O)/C=C(O)/C=C/c1ccc(O)c(O)c1</smiles><smiles>O=C(O)c1cc2oc(=O)c3cc(O)c(O)cc3c2c(=O)o1</smiles><smiles>COC(=O)c1c(O)cc(/C=C/c2ccc(O)c(O)c2)oc1=O</smiles>

Phelligridin B (18)

$$
\text { Phelligridin A (17) }
$$

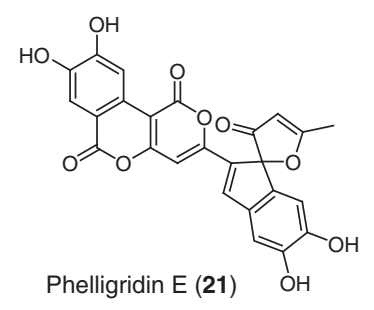<smiles>OCCCCCCO</smiles><smiles>CC1=CC=C(c2cc3oc(=O)c4cc(I)c(O)cc4c3c(=O)o2)C12OC(/C=C/c1ccc(O)c(O)c1)=CC2=O</smiles>
Phelligridin F (22)<smiles>C=C(C)c1oc2cc(/C=C/c3ccc(O)c(O)c3)oc(=O)c2c1-c1cc2oc(=O)c3cc(O)c(O)cc3c2c(=O)o1</smiles>

Phelligridin $\mathrm{H}(24)$<smiles>CCc1cc2oc(=O)c3cc(O)c(O)cc3c(=O)c2cc1O</smiles>

Phelligridin I (25)<smiles></smiles><smiles>[R]c1cc(/C=C/c2cc3oc(=O)c4cc(O)c(O)cc4c3c(=O)o2)ccc1O</smiles> 
<smiles>O=c1oc(/C=C/c2ccc(O)c(O)c2)cc2oc(-c3ccc(O)c(O)c3)cc12</smiles>

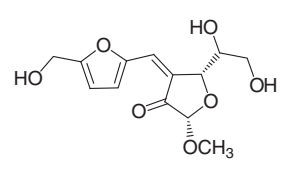

Phellinusfuran A (28)

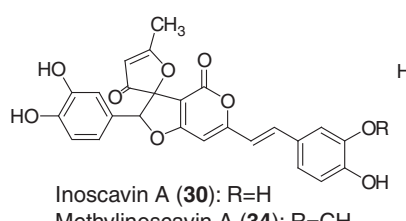

Methylinoscavin A (34): $\mathrm{R}=\mathrm{CH}_{3}$

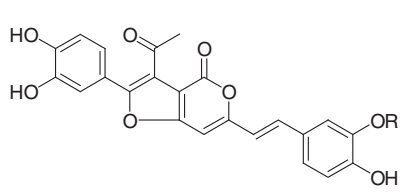

Inoscavin C (32): $\mathrm{R}=\mathrm{H}$ Methylinoscavin $\mathrm{C}$ (36): $\mathrm{R}=\mathrm{CH}_{3}$
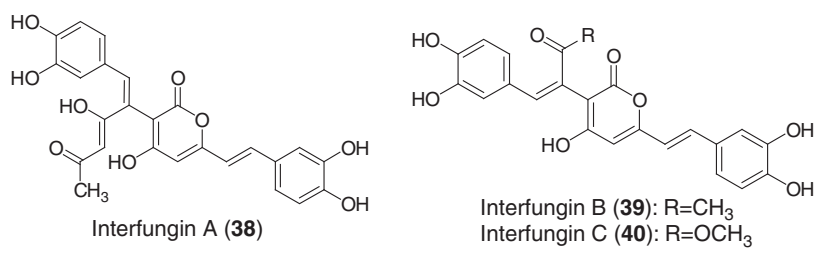

Figure 3 Structures of compounds $27-40$.

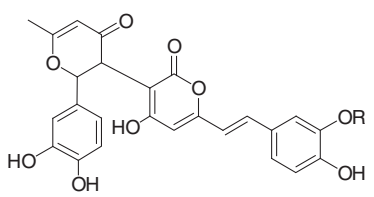

Davallialactone (41): $\mathrm{R}=\mathrm{H}$ Methyldavallialactone (42): $\mathrm{R}=\mathrm{CH}_{3}$
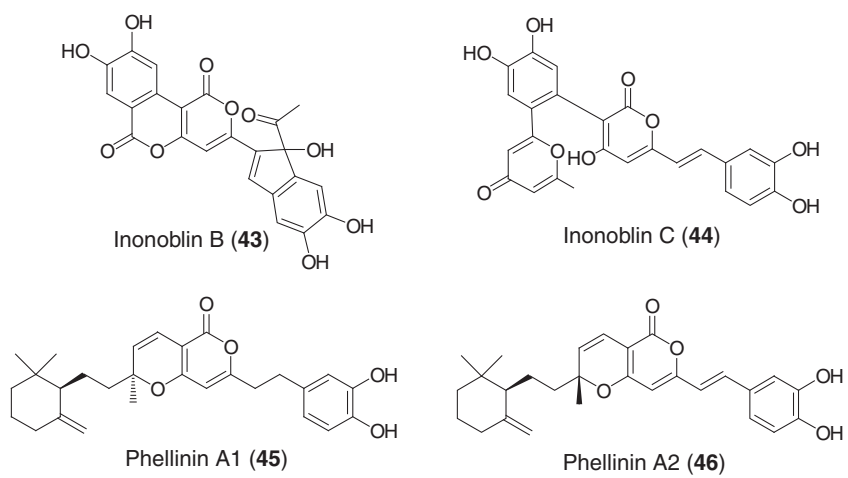

Figure 4 Structures of compounds 41-46.

group from I. xeranticus and I. obliquus, was the most potent free radical scavenger. Compounds $\mathbf{4 1}$ and $\mathbf{4 2}$ displayed significant ABTS radical scavenging activity, with $\mathrm{IC}_{50}$ values of 0.8 and $1.5 \mu \mathrm{M}$ (vitamin E, $5.7 \mu \mathrm{M}$ ), respectively. They showed DPPH radical scavenging activity, with $\mathrm{IC}_{50}$ values of 3.4 and $18.7 \mu \mathrm{M}$ (vitamin $\mathrm{E}, 12.3 \mu \mathrm{M}$ ), respectively, and superoxide radical scavenging activity, with $\mathrm{IC}_{50}$ values of 2.3 and $5.4 \mu \mathrm{M}$ (vitamin E, > $100 \mu \mathrm{M}$; caffeic acid, $2.9 \mu \mathrm{M}$ ). Compound 41 is about 2-5 times more potent than compound 42 , in which the hispidin moiety was masked by a methyl group. Inoscavin A inhibited rat liver microsomal lipid peroxidation, with an $\mathrm{IC}_{50}$ value of $0.3 \mu \mathrm{g} \mathrm{ml}^{-1}$, which is five times the potency of vitamin $\mathrm{E}\left(1.5 \mu \mathrm{g} \mathrm{ml}^{-1}\right)$. Phelligridimer A (8) and Phelligridins G-J (23-26) from the fruiting body of $P$. igniarius inhibited rat liver microsomal lipid peroxidation, with $\mathrm{IC}_{50}$ values of $10.2,3.8,4.8,3.7$ and $6.5 \mu \mathrm{M}$, respectively. ${ }^{32,39,40}$

\section{Cytotoxicity}

Hispidin (1) inhibited isoform- $\beta$ of protein kinase C ( $\mathrm{IC}_{50} 2 \mu \mathrm{M}$ ), which is more cytotoxic toward cancerous cells (pancreatic duct and keratinocyte) than normal cells (fibroblast). ${ }^{27}$ Hispolon (16) from $P$. linteus showed dose-dependent inhibition of human epidermoid $\mathrm{KB}$ cell proliferation, with an $\mathrm{IC}_{50}$ value of $4.62 \mu \mathrm{g} \mathrm{ml}^{-1}$, and induced cell death in $\mathrm{KB}$ cells through a mitochondria-mediated apoptotic pathway. ${ }^{54}$ Further research on the mechanism by which compound $\mathbf{1 6}$ induces apoptosis was recently conducted. Downregulation of the MDM2 proto-oncogene, which is overexpressed in many human tumors, has been an attractive therapeutic strategy for treatment of cancer. Compound 16 displayed anti-proliferative effects via MDM2recruited ERK1/2 activity in breast and bladder cancer cells. ${ }^{55}$ Phelligridin A-J (17-26) from P. igniarius, and phellifuropyranone A (27) from $P$. linteus showed modest in vitro cytotoxicity against several human cancer cell lines. ${ }^{38-40,42}$

\section{Anti-diabetic activity}

Diabetes mellitus is a leading cause of many complications, such as artherosclerosis, cardiac dysfunction, retinopathy, neuropathy and nephropathy. Hyperglycemia may have an important role in pathogenesis of diabetic complications through several mechanisms, such as increased aldose reductase-related polyol pathway flux and increased formation of advanced glycation end products. Thus, inhibition of aldose reductase and protein glycation is effective for treatment of diabetic complications. The fruiting body of $P$. linteus showed inhibitory activity against both. ${ }^{56,57}$ Davallialactone $(41)$, methyldavallialactone (42), hypholomine B (5), interfungin A (38) and inoscavin A (30) exhibited potent inhibitory activity against rat lens and human recombinant aldose reductases, with $\mathrm{IC}_{50}$ values of $0.33,0.51,0.82$, $1.03,1.06 \mu \mathrm{M}$ and $0.56,1.15,1.28,1.82,1.40 \mu \mathrm{M}$, respectively. Interfungin A (38) was tested as a potential compound for inhibition of protein glycation and has demonstrated potent inhibition of crosslinking of proteins, which was more effective than aminoguanidine, a well-known inhibitor of advanced glycation end products.

\section{Anti-inflammatory activity}

Inflammation is a multifaceted response mediated by activation of cells in the immune system. Of these cells, macrophages have a central role in many pathological processes during inflammation, including overproduction of inflammatory mediators, such as NO by inducible NOS (iNOS) and prostaglandin $\mathrm{E}_{2}$ by cyclooxygenase-2, and increased expression of cell surface molecules, such as CD80 and CD86. In activated RAW264.7 cells, davallialactone (41) strongly downregulated the LPS-mediated inflammatory response, including NO production, prostaglandin $\mathrm{E}_{2}$ release, expression of the proinflammatory cytokine gene and cell surface expression of co-stimulatory molecules. Treatment with compound $\mathbf{4 1}$ did not alter cell viability or morphology. Compound 41 was found to exert its anti-inflammatory effects through inhibition of a signaling cascade that activates nuclear factor 
$\kappa \mathrm{B}$ via $\mathrm{P} 13 \mathrm{~K}$, Akt and $\mathrm{IKK}$, but not mitogen-activated protein kinases. ${ }^{58}$ Treatment with 41 affected phosphorylation of these signaling proteins, but not their level of expression. These inhibitory effects were not due to interruption of toll-like receptor 4 binding to CD14. Compound 41 also inhibited LPS-induced phosphorylation and kinase activity of Src, implying that Src may be a potential pharmacological target of davallialactone (41). ${ }^{58}$

Hispidin (1) and inotilone (15) selectively inhibited cyclooxygenase- 2 at concentrations as low as those of the standard inhibitors, meloxicam and nimesulide. Hispidin (1) also showed good $3 \alpha-$ hydroxysteroid dehydrogenase and xanthine oxidase inhibitory activities. ${ }^{36}$ For the tautomeric hispidin and isohispidin (12), $\alpha$-pyrone appeared to be more active than $\gamma$-pyrone. Compared with allopurinol (IC $504.4 \mu \mathrm{M}$ ), hypholomine B (5), squarrosidine (9) and 1,1-distyrylpyrylethan (10) proved to be potent inhibitors of xanthine oxidase, with $\mathrm{IC}_{50}$ values of $6.7,8.1$ and $5.8 \mu \mathrm{M}$, respectively.

The complement system is a major effector of humoral immunity, and modulation of complement activity can be important for treatment of inflammation. Phellinusfurans A (28) and B (29) exhibited significant inhibitory activity in the classical pathway (CP) of the complement system, with $\mathrm{IC}_{50}$ values of 33.6 and $33.7 \mu \mathrm{M}$, respectively, comparable to the positive control, rosmarinic acid $\left(\mathrm{IC}_{50}\right.$ $180 \mu \mathrm{M}) .{ }^{43}$

\section{Anti-platelet aggregation activity}

Davallialactone (41) dose-dependently inhibited platelet aggregation stimulated either by collagen or by thrombin, and induced by ADP. In addition, it inhibited intracellular calcium concentration level, phosphorylation of extracellular signal-regulated protein kinase (ERK)-2 and p38 mitogen-activated protein kinase (MAPK) in a dose-dependent manner. Tyrosine phosphorylation of 60 and $85 \mathrm{kDa}$ proteins activated by collagen were shown to be differentially inhibited by $\mathbf{4 1}$. Thus, compound $\mathbf{4 1}$ may have potential anti-platelet aggregation activity via suppression of intracellular downstream signaling pathways. $^{59}$

\section{Anti-viral activity}

Hispidin (1) and hispolon (16) showed considerable anti-viral activity against influenza viruses type $\mathrm{A}(\mathrm{H} 1 \mathrm{~N} 1$ and $\mathrm{H} 3 \mathrm{~N} 2)$ and $\mathrm{B}$ using the allantois on the shell-test system. ${ }^{15} \mathrm{HIV}-1$ integrase is one of the three enzymes critical to viral replication. The other two are reverse transcriptase and protease. Development and therapeutic administration of inhibitors of the latter two enzymes had a significant effect on control of the spread of HIV infection. However, emergence of multi-drug-resistant viruses, even in drug-naïve patients, has appeared; thus, inhibition of HIV-1 integrase is one of the most promising new targets for anti-retroviral therapy. Hispidin (1) showed HIV-1 integrase inhibitory activity, with an IC $_{50}$ value of $2 \mu \mathrm{M}$ in the coupled assay system. Inhibition of HIV-1 integrase was completely abolished when the phenolic groups of hispidin were capped with a methyl ether, indicating that the acidic phenolic groups are critical to integrase inhibitory activity, a known phenomenon of this enzyme. ${ }^{60}$

\section{Anti-dementia activity}

Alzheimer's disease is a neurodegenerative disorder; a major histopatholgical characteristic of this disease is the deposition of amyloid proteins (amyloid plaques) in the parenchyma of the amygdale, hippocampus and neocortex. $\beta$-amyloid peptide $(A \beta)$, which is formed by $\alpha$-, $\beta$-, and $\gamma$-secretase through cleavage of the amyloid precursor protein, is the major component of amyloid plaques.
Among these secretases, BACE1 ( $\beta$-site amyloid precursor protein cleaving enzyme) is at present the most attractive target for inhibition of amyloid production. Thus, BACE1 inhibitors should reduce A $\beta$ levels. Hispidin (1) from the mycelial culture of $P$. linteus noncompetitively inhibited BACE1 in a dose-dependent manner, showing an $\mathrm{IC}_{50}$ value of $4.9 \mu \mathrm{m}$. In addition, hispidin (1) appeared to be a relatively specific inhibitor of BACE1 and prolyl endopeptidase, as it showed no activity against TACE (tumor necrosis factor alpha converting enzyme) and other serine proteases, such as chymotrypsin, trypsin and elastase. ${ }^{28}$

\section{BIOSYNTHESIS OF STYRYLPYRONES}

Biosynthesis of hispidin (1) has been studied at labeling experiment level; however, that for other styrylpyrones remains postulative. Incorporation of $\left[1-{ }^{14} \mathrm{C}\right]$ acetate and $\left[\mathrm{U}_{-}{ }^{14} \mathrm{C}\right] \mathrm{L}-\mathrm{Phe}$ into $\mathbf{1}$ in Polyporus schweinizii indicated that it is derived from phenylpropanoid and two acetate units. Tracer studies showed incorporation of D,L-Phe (47), D,Ltyrosine (49), cinnamate (48), $p$-coumarate (50) and caffeate (11) into the styryl unit, and efficient incorporation of acetate and malonate into the pyrone ring. ${ }^{25}$ In addition, $p$-coumaric acid hydroxylase in I. hispidus has been reported to exist as two forms, E1 and E2. ${ }^{61}$ These enzymes were capable of hydroxylation of $p$-coumaric acid (50) and bis-noryangonin (2) into caffeic acid (11) and hispidin (1), respectively, suggesting a potential alternative route for synthesis of hispidin from $p$-coumaric acid (50) without involvement of caffeic acid (11) as an intermediate (Figure 5). Thus, it has been suggested that bisnoryangonin (2) may not be found naturally in Phellinus and Inonotus spp., and that this metabolite exists mainly in Gymnopilus and Pholiota spp. rather than Phellinus and Inonotus spp. Another biosynthetic pathway mediated by 4-hydroxy-6-methyl-2-pyrone (51), which is formed by the reaction of three units of acetyl-CoA and one 3,4dihydroxybenzoyl-CoA (3,4-dihydroxy benzaldehyde) (52), has been proposed; this pathway resulted from co-occurrence of $\mathbf{5 2}$ and 3,4dihydroxybenzoic acid with styrylpyrone metabolites (Figure 6). ${ }^{38}$

Light is required for hispidin biosynthesis in I. hispidus in order to initiate a sequential increase in the activity of enzymes involved in production of styrylpyrones. ${ }^{62,63}$ Not only pigment formation, but also cinnamate and $p$-coumarate hydroxylase activity and tyrosine ammonia-lyase and aminotransferase activity for Phe were stimulated by light. These findings were supported by results from a previous study, in which production of phenolic compounds by I. obliquus was enhanced under oxidative stress. Yield and composition of polyphenols, including phelligridins and inoscavins, can be considerably increased or extensively modified by addition of $\mathrm{H}_{2} \mathrm{O}_{2}$ or $\mathrm{H}_{2} \mathrm{O}_{2}$ and arbutin. ${ }^{64}$ These conditions affected the diversity of styrylpyrones found in wild mushroom and mycelial cultures in different ways. Metabolites isolated from wild mushrooms have been reported to have greater complexity with greater structural diversity than those from the mycelial cultures or cultivated mushrooms, which are more vulnerable to microbial attacks, ultraviolet radiation and other conditions. It has been proposed that the polyphenols from the wild mushrooms are biosynthesized mainly via oxidative coupling of the precursors hispidin (1) and hispolon (16), or 3,4-dihydroxyphenylpropanoids by mushroom peroxidase (Figures 7 and 8). On the other hand, hispidin (1) and its dimer are the metabolites isolated from the mycelial cultures or cultivated mushrooms; the dimer is generated by the oxidative coupling of two units of hispidin (1), specifically through condensation of dehydrohispidin by the ligninolytic enzyme (Figure 10). ${ }^{34}$

As shown in Figures 7 and 8, hispolon (16) and 4-(3,4-dihydroxyphenyl)-3-buten-2-one (13) might be biosynthesized by coupling 
of either 3,4-dihydroxybenzaldehyde and two or three acetates, or cinnamoyl-CoA and one or two acetates, followed by decarboxylation. Interfungins $\mathrm{A}(\mathbf{3 8})$ and $\mathrm{B}(39)$ might be biogenerated by condensation of 1 and 16 and 1 and 13, respectively; this process may be catalyzed by mushroom peroxidase. The natural and/or enzymatic rearrangement of the highly functionalized metabolites $\mathbf{3 8}$ and $\mathbf{3 9}$ may provide mechanistic insight for formation of mushroom polyphenols, such as inoscavins A-C (30-32), davallialactone (41) and phelligridin $\mathrm{F}$ (22) (Figures 7 and 8$).{ }^{49}$

Compounds containing the 8,9-dihydroxy- $1 H, 6 H$-pyrano[4,3-c] [2] benzopyran-1,6-dione moiety could be formed by coupling of three units of acetyl-CoA and 3,4-dihydroxy benzoic acid or 3,4dihydroxybenzaldehyde. Further coupling of hispidin with 4-hydroxybenzoic acid or 3,4-dihydroxybenzoic acid would generate phelligridin C (19) or phelligridin D (20), and coupling of hispidin with 3,4-dihydroxybenzaldehyde (52) would give inoscavin D (33) (Figure 9). ${ }^{48}$ These metabolites could also be produced by coupling of hispidin or bis-noryangonin with 3,4-dihydroxybenzoyl-CoA. Phelligridin E (21) might be formed via coupling of phelligridin D (20) with 4-hydroxy-6-methyl-2-pyrone (51), and further reaction by phelligridin E (21) and 3,4-dihydroxybenzaldehyde (52) would generate phelligridin $\mathrm{F}(\mathbf{2 2}){ }^{39}$

Hispidin (1) may be transformed into more elaborate metabolites by coupling with a second pyrone. Mycelial cultures of Phellinus and Inonotus sp. produced hispidin (1) and its dimers, 3,14'-bihispidinyl (3), hypholomine B (5) and 1,1-distyrylpyrylethan (10), which could be regarded as condensation products of dehydrohispidin. In addition, the mechanism of dipyrone formation for phelligridimer A (8), squarrosidine (9), and fasciculins A (6) and B (7) could be similar. Formation of 3,14'-bihispidinyl (3) was proposed by initial oxidation of hispidin (1) to dehydrohispidin, followed by conjugative attack at the ortho-quinone by the nucleophilic (C-3) center of the pyrone ring in a second hispidin (Figure 10). ${ }^{20}$ Hypholomines A (4) and B (5) might result from attack at the electrophilic double bond by the nucleophilic C-3 of the pyrone ring in hispidin (1) and bis-noryan- gonin (2), respectively, followed by formation of the dihydrofuran ring. ${ }^{10}$ However, hypholomine A was not detected due to deficiency of bis-noryangonin (2) in Phellinus and Inonotus spp. Phelligridimer A (8) may be sequentially or simultaneously formed from oxidative coupling of four hispidins and/or from two units of hypholomine B (5). ${ }^{32}$ Bis-styrylyrones squarrosidine (9) and 1,1-distyrylpyrylethan (10) represent new members of the fungal phenylpropanoids with an unprecedented 3,3'-fusion. Their formation can be rationalized by nucleophilic vinylogous addition of the enol of hispidin (1) to a tautomeric form of a methylated hispidin derivative, followed by methylation of the methylene bridge, generating 1,1-distyrylpyrylethan (10). ${ }^{33}$ Fasciculins A (6) and B (7) from Hypholoma and Pholiota sp. presumably arise by condensation with 6-(4'-hydroxyphenyl)-4hydroxy-2-pyrone and 6-(3',4'-dihydroxyphenyl)-4-hydroxy-2-pyrone, respectively. ${ }^{20}$ Nevertheless, the arylpyrones implicated in biosynthesis of fasciculins have not yet been isolated from Phellinus and Inonotus sp.

Yangonin (55), a 4-methoxy-6-(4-methoxystyryl)-2-pyrone, was first isolated from the plant Piper methysticum, which has been used in treatment of anxiety, nervous tension, agitation and insomnia. ${ }^{18,65}$ Its pharmacological effects are associated with a group of styrylpyrones termed kavapyrones, including kawain (53), dihydrokawain (54),

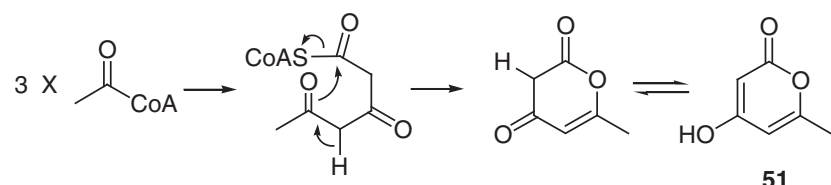<smiles>Cc1cc(O)cc(=O)o1</smiles>

Figure 6 Proposed biosynthetic pathways of hispidin (1)<smiles>NC(Cc1ccccc1)C(=O)O</smiles>

49<smiles>Cc1ccc(/C=C/C(=O)O)cc1</smiles><smiles>C=[IH]</smiles><smiles>O=C(O)/C=C/c1ccccc1</smiles><smiles>O=C(O)COC(=O)CC(=O)O</smiles><smiles>C=CCO</smiles><smiles>C1CCCC1</smiles><smiles>O=C(O)/C=C/c1ccc(O)cc1</smiles>

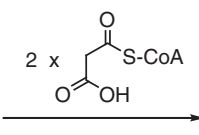

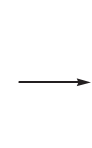

11<smiles>O=C(O)COC(=O)CC(=O)CC(=O)CC(=O)OCC(=O)O</smiles><smiles>O=c1cc(O)cc(/C=C/c2ccccc2)o1</smiles><smiles>O=c1cc(O)cc(/C=C/c2ccc(O)cc2)o1</smiles><smiles>O=c1cc(O)cc(/C=C/c2ccc(O)c(O)c2)o1</smiles>

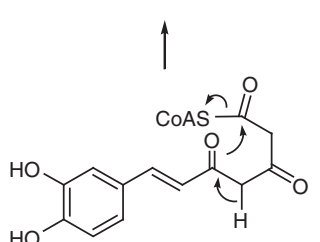

Figure 5 Proposed biosynthetic pathways of hispidin (1). 


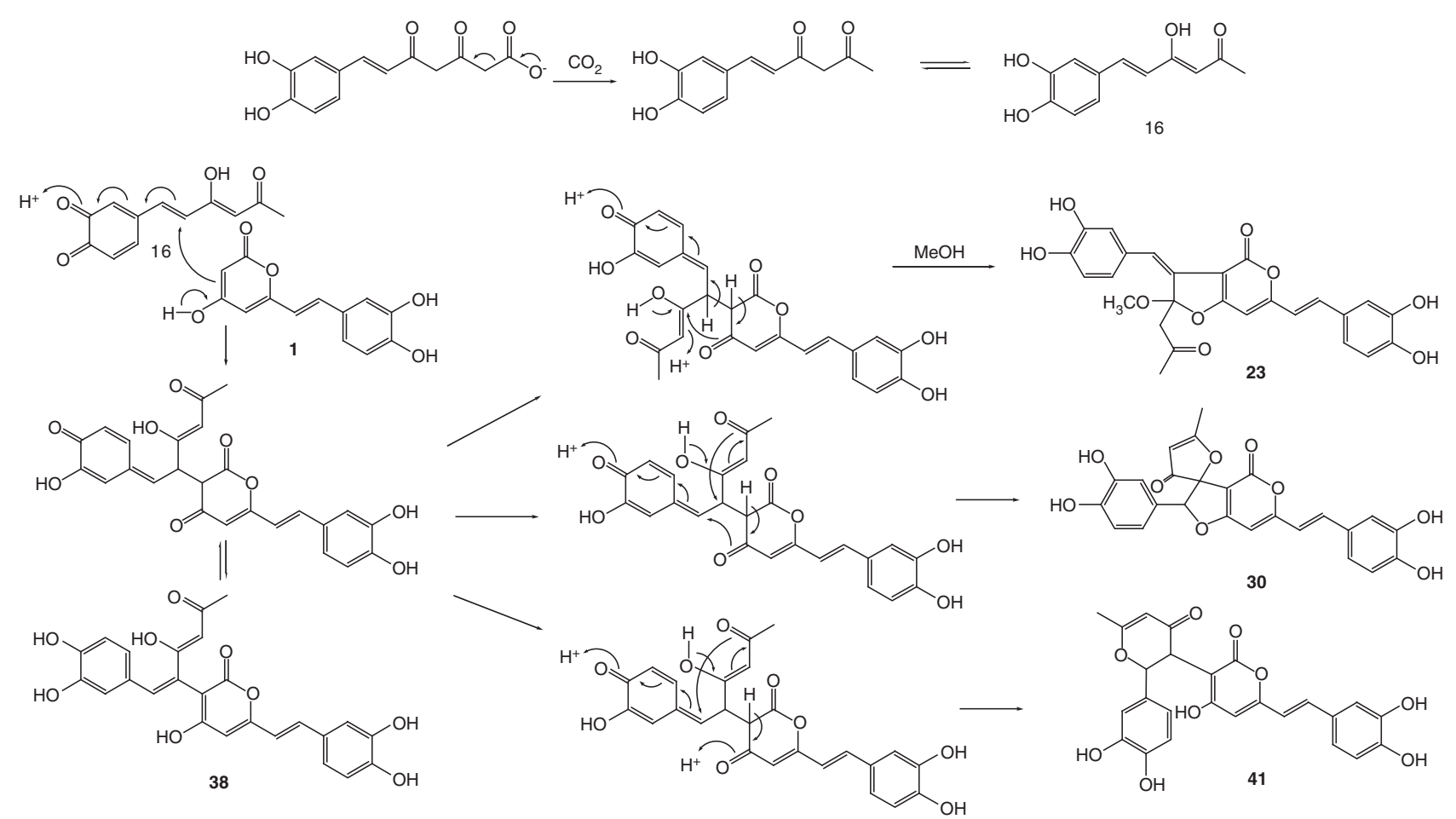

Figure 7 Proposed biosynthetic pathways of phelligridin G (23), inoscavin A (30) and davallialactone (41).<smiles>CC(=O)/C=C/c1ccc(O)c(O)c1</smiles>

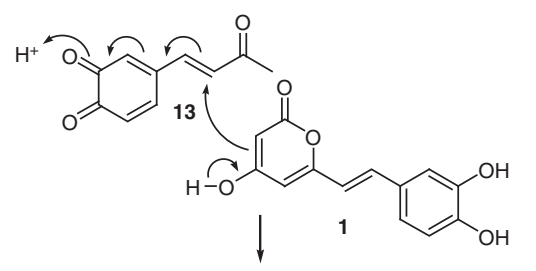

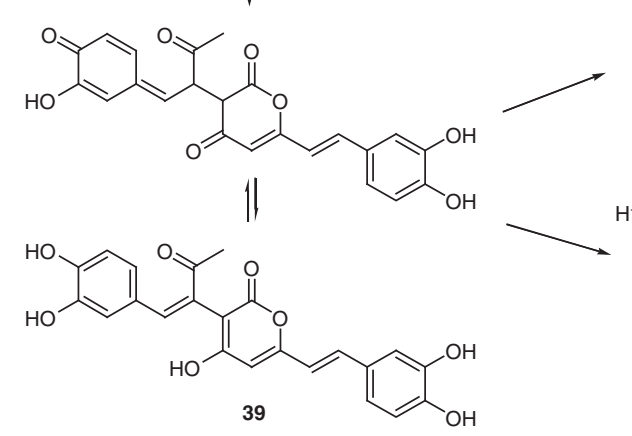

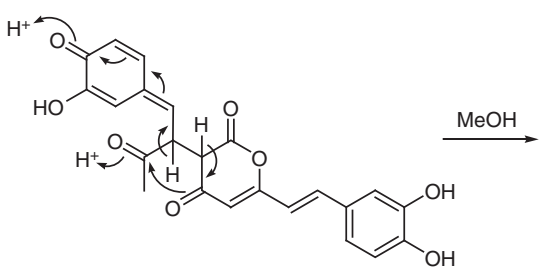<smiles>CC1(C)Oc2cc(/C=C/c3ccc(O)c(O)c3)oc(=O)c2/C1=C\c1ccc(O)c(O)c1</smiles>

Figure 8 Proposed biosynthetic pathways of inoscavins B (31) and C (32).

yangonin (55), demethoxyyangonin (56), methysticin (57) and dihydromethysticin (58) (Figure 11). The C-4 methyl group on the pyrone ring, which is different from that of fungal styrylpyrones, is the common characteristic of these kavapyrones. Biosynthesis of styrylpyrone has been extensively studied in the plant Equisetum arvense, in which styrylpyrones and flavonoids constitutively accumu- late in distinct organs, and styrylpyrones and caffeic acid derivatives may act as effective resistance factors, which appear to have similar ecological and physiological roles as fungal styrylpyrones. ${ }^{17}$ Equisetumpyrone (59), a styrylpyrone glucoside in gametophytes from Equisetum arvense, differs in the oxygenation pattern of its pyrone ring from the fungal styrylpyrones, which are never oxygenated at 


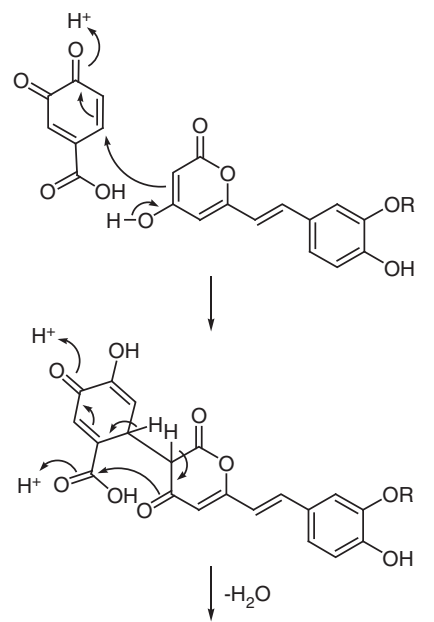

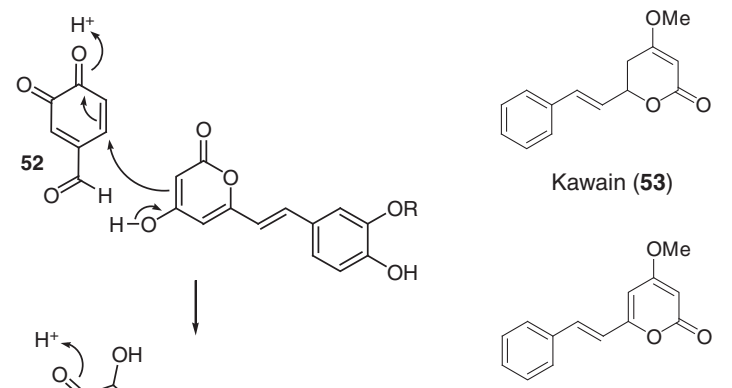

Demethoxyyangonin (56)<smiles>COC1=CC(=O)OC(CCc2ccccc2)C1</smiles><smiles>COc1ccc(/C=C/c2cc(OC)cc(=O)o2)cc1</smiles><smiles>COC1=CC(=O)OC(/C=C/c2ccc3c(c2)OCO3)C1</smiles>

Methysticin (57)<smiles>COC1C=C(C)CC(CCc2ccc3c(c2)OCO3)O1</smiles>

Dihydromethysticin (58)

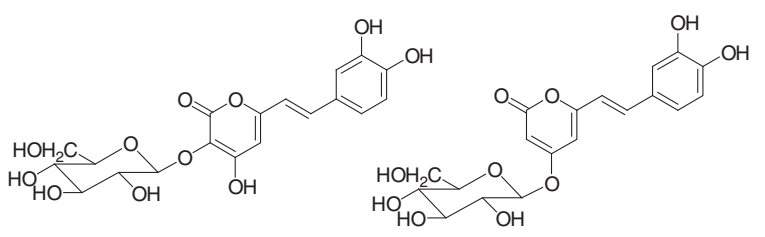

Equisetumpyrone (59) Hispidin 4-O- $\beta$-D-glucopyranoside (60)

Figure 11 Structures of compounds 53-60.

33: $\mathrm{R}=\mathrm{H}$ 37: $\mathrm{R}=\mathrm{CH}_{3}$

Figure 9 Proposed biosynthetic pathways of phelligridins $C(19)$ and $D(20)$, inoscavin D (33) and methylinoscavin D (37).<smiles>[X]c1ccc(/C=C/C2=CC(O)=CC(OC(C)C)O2)cc1O</smiles><smiles>O=c1cc(O)cc(/C=C/c2cc(O)c(O)cc2-c2ccc(/C=C/c3ccc(O)c(O)c3)oc2=O)o1</smiles>

Figure 10 Proposed dimerization mechanism of hispidin (1) into 3,14'bihispidinyl (3) by horseradish peroxidase.

C-3. ${ }^{66,67}$ Moreover, hispidin 4-O- $\beta$-D-glucopyranoside (60), an inhibitor of both low-density lipoprotein oxidation and ROS production, is glycosylated at C-4 (Figure 11). ${ }^{68}$ In Phellinus and Inonotus spp., however, no glycosides of styrylpyrones have been found. Thus, it appears that styrylpyrones originating from plants and fungi are biosynthesized from a similar pathway, but possess different structural features, possibly due to environmental differences.

\section{CONCLUSIONS}

The fruiting bodies of P. linteus, P. igniarius, P. ribis, I. obliquus and I. xeranticus, belonging to the genera Phellinus and Inonotus, have been used as traditional medicines in Asian countries. Polysaccharides, particularly $\beta$-glucan, have received significant attention, and a number of polysaccharides and protein-bound polysaccharides from medicinal mushrooms have been developed for treatment of cancer. Krestin, Mesima, Lentinan and Schizophylan are clinically used representatives. However, there is little evidence to show that polysaccharides are solely responsible for the biological effects of medicinal mushrooms. The biological effects of the methanolic extract of the fruiting bodies of these medicinal fungi have been reported; however, only a few studies have reported on the active principles of the extract. Many research groups have begun identification of the active ingredients of medicinal mushrooms. In addition, researchers have also attempted to determine the chemical constituents, aside from polysaccharides, that are responsible for the biological activity of medicinal mushrooms, with a particular focus on the yellow polyphenol pigments (Table 1). Styrylpyrone-type polyphenol pigments showed various biological activities, including anti-oxidative, anti-inflammatory, cytotoxic, anti-platelet aggregation, anti-diabetic, anti-dementia and anti-viral effects. Unfortunately, these mushrooms are rare in nature; consequently, their use is restricted. Therefore, cultivation and mycelial fermentation have been developed for mushrooms. ${ }^{69-71}$ Styrylpyrone composition of wild-grown and cultivated $P$. linteus and the cultured mycelia differed from each other. $^{72}$ This may be attributed to environmental factors, such as microbial attack, ultraviolet radiation and oxidative stress. Nevertheless, the cultivated mushroom or cultured mycelia of $P$. linteus exhibited biological activities comparable to the wild-grown mushroom, and produced an abundant amount of yellow pigments containing mainly styrylpyrones with various biological activities. ${ }^{28,29,34,52-57,60,64,72-75}$ In addition, the adverse effects of the medicinal mushrooms Phellinus and Inonotus have not been reported until now. Methanolic extracts of $I$. xeranticus did not show acute toxicity up to $2 \mathrm{~g} \mathrm{~kg}^{-1}$ in mice, and the $\mathrm{LD}_{50}$ values of these extracts were above $2 \mathrm{~g} \mathrm{~kg}^{-1}$, indicating the safe nature of these mushrooms. ${ }^{76}$ Therefore, medicinal mushrooms Phellinus and Inonotus hold great promise for use in pharmacological applications. This is especially true for the styrylpyrone class of yellow pigments, which might be a good candidate for use in drug discovery. 


\section{ACKNOWLEDGEMENTS}

This work was supported by a grant from the Korea Forest Service and, in part, by Basic Science Research Program through the National Research Foundation of Korea (NRF) funded by the Ministry of Education, Science and Technology (2010-0005844), Republic of Korea.

1 Quang, D. N., Hashimoto, T. \& Asakawa, Y. Inedible mushrooms: a good source of biologically active substances. Chem. Rec. 6, 79-99 (2006).

2 Barros, L., Cruz, T., Baptista, P., Estevinho, L. M. \& Ferreira, I. C. Wild and commercial mushrooms as source of nutrients and nutraceuticals. Food Chem. Toxicol. 46, 2742-2747 (2008).

3 Cohen, R., Persky, L. \& Hadar, Y. Biotechnological applications and potential of wood-degrading mushrooms of the genus Pleurotus. Appl. Microbiol. Biotechnol. 58, 582-594 (2002).

4 Russell, R. \& Paterson, M. Ganoderma-a therapeutic fungal biofactory. Phytochemistry 67, 1985-2001 (2006).

5 Cui, J. \& Chisti, Y. Polysaccharopeptides of Coriolus versicolor: physiological activity, uses, and production. Biotechnol. Adv. 21, 109-122 (2003).

6 Hobbs, C. Medicinal Mushrooms, an Exploration of Tradition Healing and Culture, Interweave Press Inc, New York, (1986).

7 Yamasaki, A. et al. A protein-bound polysaccharide, PSK, enhances tumor suppression induced by docetaxel in a gastric cancer xenograft model. Anticancer Res. 29, 843-850 (2009).

$8 \mathrm{Li}, \mathrm{G}$. et al. Protein-bound polysaccharide from Phellinus linteus induces G2/M phase arrest and apoptosis in SW480 human colon cancer cells. Cancer Lett. 216, 175-181 (2004).

9 Zhou, L. D., Zhang, Q. H., Zhang, Y., Liu, J. \& Cao, Y. M. The shiitake mushroomderived immuno-stimulant lentinan protects against murine malaria blood-stage infection by evoking adaptive immune-responses. Int. Immunopharmacol. 9, 455462 (2009).

10 Kumari, M., Survase, S. A. \& Singhal, R. S. Production of schizophyllan using Schizophyllum commune NRCM. Bioresour. Technol. 99, 1036-1043 (2008).

$11 \mathrm{Zhu}, \mathrm{T}$. et al. Phellinus linteus activates different pathways to induce apoptosis in prostate cancer cells. Br. J. Cancer 96, 583-590 (2007).

12 Guo, J. et al. Modulation of lung cancer growth arrest and apoptosis by Phellinus Linteus. Mol. Carcinog. 46, 144-154 (2007).

13 Choi, Y. H. et al. Inhibition of anaphylaxis-like reaction and mast cell activation by water extract from the fruiting body of Phellinus linteus. Biol. Pharm. Bull. 29, 1360-1365 (2006).

14 Cui, Y., Kim, D. S. \& Park, K. C. Antioxidant effect of Inonotus obliquus. J. Ethnopharmacol. 96, 79-85 (2005).

15 Awadh Ali, N. A., Mothana, R. A., Lesnau, A., Pilgrim, H. \& Lindequist, U. Antiviral activity of Inonotus hispidus. Fitoterapia 74, 483-485 (2003).

16 Fiasson, J. L. Distribution of styrylpyrones in the basidiocarps of various Hymenochaetaceae. Biochem. Syst. Ecol. 10, 289-296 (1982).

17 Beckert, C. et al. Styrylpyrone biosynthesis in Equisetum arvense. Phytochemistry 44 275-283 (1997).

18 Dewick, P. M. Medicinal Natural Products-2nd Edition a Biosynthetic Approach 147-148 (John Wiley \& Sons Ltd, Chichester, UK, 2001).

19 Turner, W. B. \& Aldrige, D. C. Fungal metabolites II, Academic press Inc, London, pp 26-31 (1983).

20 Gill, M. \& Steglich, W. Progress in the chemistry of organic natural products. Fortschr. Chem. Org. Naturst. 51, 88-99 (1987).

21 Gill, M. Pigments of fungi (Macromycetes). Nat. Prod. Rep. 11, 67-90 (1994).

22 Gill, M. Pigments of fungi (Macromycetes). Nat. Prod. Rep. 20, 615-639 (2003)

23 Gill, M. The biosynthesis of pigments in basidiomycetes. Aust. J. Chem. 54, 721-734 (2001).

24 Perrin, P. W. \& Towers, G. H. N. Metabolism of aromatic acids by Polyporus hispidus. Phytochemistry 12, 583-588 (1973).

25 Perrin, P. W. \& Towers, G. H. N. Hispidin biosynthesis in cultures of Polyporus hispidus. Phytochemistry 12, 589-592 (1973).

26 Hatfied, G. M. \& Brady, L. R. Biosynthesis of hispidin in cultures of Polyporus schweinitzii. Lloydia 36, 59 (1973).

27 Gonindard, C. et al. Synthetic hispidin, a PKC inhibitor, is more cytotoxic toward cancer cells than normal cells in vitro. Cell Biol. Toxicol. 13, 141-153 (1997).

28 Park, I. H., Jeon, S. Y., Lee, H. J., Kim, S. I. \& Song, K. S. A $\beta$-secretase (BACE1) inhibitor hispidin from the mycelial cultures of Phellinus linteus. Planta Med. 70, 143-146 (2004).

29 Park, I. H. et al. An antioxidant hispidin from the mycelial cultures of Phellinus linteus. Arch. Pharm. Res. 27, 615-618 (2004)

30 Klaar, M. \& Steglich, W. Isolierung von hispidin und 3,14-bihispidinyl aus Phellinus pomaceus (Poriales). Chem. Ber. 110, 1058-1062 (1977).

31 Fiasson, J. L., Gluchoff Fiasson, K. \& Steglich, W. Über die Farb- und Fluoreszenzstoffe des Grünblättrigen Schwefelkopfes (Hypholoma fasciculare, Agaricales). Chem. Ber. 110, 1047-1057 (1977).

32 Wang, Y. et al. Phelligridimer A, a highly oxygenated and unsaturated 26-membered macrocyclic metabolite with antioxidant activity from the fungus Phellinus igniarius. Org. Lett. 7, 4733-4736 (2005).
33 Kemami Wangun, H. V. \& Hertweck, C. Squarrosidine and Pinillidine: 3,3'-Fused Bis (styrylpyrones) from Pholiota squarrosa and Phellinus pini. Eur. J. Org. Chem. 2007, 3292-3295 (2007).

34 Jung, J. Y. et al. Antioxidant polyphenols from the mycelial culture of the medicinal fungi Inonotus xeranticus and Phellinus linteus. J. Appl. Microbiol. 104, 1824-1832 (2008).

35 Lee, I. K. \& Yun, B. S. Peroxidase-mediated formation of the fungal polyphenol 3,14'bihispidinyl. J. Microbiol. Biotechnol. 18, 107-109 (2008).

36 Wangun, H. V., Härtl, A., Tam Kiet, T. \& Hertweck, C. Inotilone and related phenylpropanoid polyketides from Inonotus $S p$. and their identification as potent $\mathrm{COX}$ and $\mathrm{XO}$ inhibitors. Org. Biomol. Chem. 4, 2545-2548 (2006).

37 Ali, N. A. A., Pilgrim, H., Liberra, K., Lindequist, U. \& Jansen, R. Hispolon, a yellow pigment from Inonotus hispidus. Phytochemistry 41, 927-929 (1996).

$38 \mathrm{Mo}, \mathrm{S}$. et al. Phelligridins C-F: Cytotoxic pyrano[4,3-c][2]benzopyran-1,6-dione and furo[3,2-c] pyran-4-one derivatives from the fungus Phellinus igniarius. J. Nat. Prod. $67,823-828$ (2004)

39 Wang, $\mathrm{Y}$. et al. A unique highly oxygenated pyrano[4,3-c][2]benzopyran-1,6-dione derivative with antioxidant and cytotoxic activities from the fungus Phellinus igniarius. Org. Lett. 7, 1675-1678 (2005).

40 Wang, Y. et al. Structures, biogenesis, and biological activities of pyrano[4,3-c]isochromen-4-one derivatives from the fungus Phellinus igniarius. J. Nat. Prod. 70, 296-299 (2007).

41 Nagatsu, A. et al. Identification of novel substituted fused aromatic compounds, meshimakobnol A and B, from natural Phellinus linteus fruit body. Tetrahedron Lett. 45, 5931-5933 (2004).

42 Kojima, K., Ohno, T., Inoue, M., Mizukami, H. \& Nagatsu, A. Phellifuropyranone A: a new furopyranone compound isolated from fruit bodies of wild Phellinus linteus. Chem. Pharm. Bull. 56, 173-175 (2008).

43 Min, B. S. et al. Two novel furan derivatives from Phellinus linteus with anti-complement activity. Bioorg. Med. Chem. Lett. 16, 3255-3257 (2006).

44 Lee, I. K., Kim, Y. S., Seok, S. J. \& Yun, B. S. Inoscavin E, a free radical scavenger from fruiting bodies of Inonotus xeranticus. J. Antibiot. 60, 745-747 (2007).

$45 \mathrm{Kim}$, J. P., Yun, B. S., Shim, Y. K. \& Yoo, I. D. Inoscavin A, a new free radical scavenger the mushroom Inonotus xeranticus. Tetrahedron Lett. 40, 6643-6644 (1999).

46 Lee, I. K., Seok, S. J., Kim, W. K. \& Yun, B. S. Hispidin derivatives from the mushroom Inonotus xeranticus and their antioxidant activity. J. Nat. Prod. 69, 299-301 (2006)

47 Lee, I. K. \& Yun, B. S. Hispidin analogs from the mushroom Inonotus xeranticus and their free radical scavenging activity. Bioorg. Med. Chem. Lett. 16, 2376-2379 (2006).

48 Lee, I. K., Jung, J. Y., Seok, S. J., Kim, W. G. \& Yun, B. S. Free radical scavengers from the medicinal mushroom Inonotus xeranticus and their proposed biogenesis. Bioorg. Med. Chem. Lett. 16, 5621-5624 (2006).

49 Lee, I. K. \& Yun, B. S. Highly oxygenated and unsaturated metabolites providing a diversity of hispidin class antioxidant in the medicinal mushrooms Inonotus and Phellinus. Bioorg. Med. Chem. 15, 3309-3314 (2007).

50 Cui, C. B et al. Constituents of a fern, davallia mariesii moore. I. isolation and structures of davallialactone and a new flavanone glucuronide. Chem. Pharm. Bull. 38, 3218-3225 (1990).

51 Lee, I. K., Kim, Y. S., Jang, Y. W., Jung, J. Y. \& Yun, B. S. New antioxidant polyphenols from the medicinal mushroom Inonotus obliquus. Bioorg. Med. Chem. Lett. 17, 6678-6681 (2007).

52 Lee, I. K., Seo, G. S., Jeon, N. B., Kang, H. W. \& Yun, B. S. Phellinins A1 and A2, new styrylpyrones from the culture broth of Phellinus sp. KACC93057P: I. Fermentation, taxonomy, isolation and biological properties. J. Antibiot. 62, 631-634 (2009).

53 Lee, I. K., Jung, J. Y., Kim, Y. H. \& Yun, B. S. Phellinins A1 and A2, new styrylpyrones from the culture broth of Phellinus sp. KACC93057P: II. Physicochemical properties and structure elucidation. J. Antibiot. 62, 635-637 (2009).

54 Chen, W., He, F. Y. \& Li, Y. Q. The apoptosis effect of hispolon from Phellinus linteus (Berkeley \& Curtis) Teng on human epidermoid KB cells. J. Ethnopharmacol. 105, 280-285 (2006).

$55 \mathrm{Lu}, \mathrm{T}$. L. et al. Hispolon from Phellinus linteus has antiproliferative effects via MDM2recruited ERK1/2 activity in breast and bladder cancer cells. Food Chem. Toxicol. 47, 2013-2021 (2009).

56 Lee, Y. S. et al. Inhibitory constituents of aldose reductase in the fruiting body of Phellinus linteus. Biol. Pharm. Bull. 31, 765-768 (2008).

57 Lee, Y. S. et al. Protein glycation inhibitors from the fruiting body of Phellinus linteus. Biol. Pharm. Bull. 31, 1968-1972 (2008).

58 Lee, Y. G. et al. Src kinase-targeted anti-inflammatory activity of davallialactone from Inonotus xeranticus in lipopolysaccharide-activated RAW2647 cells. Br. J. Pharmacol. 154, 852-863 (2008).

$59 \mathrm{Kim}, \mathrm{S}$. D. et al. The mechanism of anti-platelet activity of davallialactone: involvement of intracellular calcium ions, extracellular signal-regulated kinase 2 and p38 mitogenactivated protein kinase. Eur. J. Pharmacol. 584, 361-367 (2008).

60 Singh, S. B. et al. Isolation, structure, and HIV-1-integrase inhibitory activity of structurally diverse fungal metabolites. J. Ind. Microbiol. Biotechnol. 30, 721-731 (2003).

61 Nambudiri, A. M. D., Vance, C. P. \& Towers, G. H. N. Styrylpyrone biosynthesis in Polyporus hispidus. II. Enzymic hydroxylation of p-coumaric acid and bis-noryangonin. Biochim. Biophys. Acta 343, 148-155 (1974).

62 Nambudiri, A. M. D., Vance, C. P. \& Towers, G. H. N. Effect of light on enzymes of phenylpropanoid metabolism and hispidin biosynthesis in Polyporus hispidus. Biochem. J. 134, 891-897 (1973). 
63 Vance, C. P., Tregunna, E. B., Nambudiri, A. M. D. \& Towers, G. H. N. Styrylpyrone biosynthesis in Polyporus hispidus. I. Action spectrum and photoregulation of pigment and enzyme formation. Biochim. Biophys. Acta 343, 138-147 (1974).

64 Zheng, W. et al. Accumulation of antioxidant phenolic constituents in submerged cultures of Inonotus obliquus. Bioresour. Technol. 100, 1327-1335 (2009).

65 Briskin, D. P. Medicinal plants and phytomedicines. Linking plant biochemistry and physiology to human health. Plant Physiol. 124, 507-514 (2000).

66 Veit, M. et al. Equisetumpyrone, a styrylpyrone glucoside in gametophytes from Equisetum arvense. Phytochemistry 32, 1029-1032 (1993).

67 Veit, M. et al. Styrylpyrone glucosides from equisetum. Phytochemistry 39, 915-917 (1995).

68 Wei, H. A. et al. Inhibition of low-density lipoprotein oxidation and oxidative burst in polymorphonuclear neutrophils by caffeic acid and hispidin derivatives isolated from sword brake fern (Pteris ensiformis Burm.). J. Agric. Food Chem. 55, 10579-10584 (2007).

69 Sanchez, C. Modern aspects of mushroom culture technology. Appl. Microbiol. Biotechnol. 64, 756-762 (2004)
70 Hwang, H. J., Kim, S. W., Choi, J. W. \& Yun, J. W. Production and characterization of exopolysaccharides from submerged culture of Phellinus linteus KCTC 6190. Enzyme Microb. Technol. 33, 309-319 (2003).

71 Zhong, J. J. \& Tang, Y. J. Submerged cultivation of medicinal mushrooms for production of valuable bioactive metabolites. Adv. Biochem. Eng. Biotechnol. 87, 25-59 (2004).

72 Kojima, K., Ogihara, Y., Sakai, Y., Mizukami, H. \& Nagatsu, A. HPLC profiling of Phellinus linteus. Nat. Med. 62, 441-446 (2008).

$73 \mathrm{Kim}$, B. C. et al. The anti-inflammatory activity of Phellinus linteus (Berk. \& M.A. Curt.) is mediated through the PKCdelta/Nrf2/ARE signaling to up-regulation of heme oxygenase-1. J. Ethnopharmacol. 113, 240-247 (2007).

74 Hur, J. M. et al. Antibacterial effect of Phellinus linteus against methicillin-resistant Staphylococcus aureus. Fitoterapia 75, 603-605 (2004).

$75 \mathrm{Kim}, \mathrm{S}$. H. et al. Mycelial culture of Phellinus linteus protects primary cultured rat hepatocytes against hepatotoxins. J. Ethnopharmacol. 95, 367-372 (2004).

76 Kang, E. H. et al. Anti-obesity activity, anti-cancer activity and single oral dose toxicity of Inonotus xeranticus extracts. J. Toxicol. Pub. Health. 23, 253-261 (2007). 